ARTICLE HISTORY: Received: July 19, 2021 Accepted: August 12, 2021 Published: August 19, 2021

\title{
SOME POLICIES TO IMPROVE THE QUALITY OF HUMAN RESOURCES IN SOUTH KOREA AND SINGAPORE BETWEEN 1961 AND 1979
}

Tran Thi Thanh Huyen

Lecturer

Department of Languages and Cultures of Southeast Asia VNU University of Languages and International Studies

PhD student

Faculty of Oriental Studies, VNU University of Social Sciences and Humanities

Hanoi, Vietnam

Phan Minh Chau

Lecturer

Department of Vietnamese Studies, Faculty of Professional Development Thua Thien Hue College of Pedagogy,

Hue, Vietnam

PhD student

Faculty of Oriental Studies, VNU University of Social Sciences and Humanities

Hanoi, Vietnam

\section{НЕКОТОРЫЕ ПОЛИТИКИ ПО ПОВЫШЕНИЮ КАЧЕСТВА ЛЮДСКИХ РЕСУРСОВ В ЮЖНОЙ КОРЕЕ И СИНГАПУРЕ В ПЕРИОД С 1961 ПО 1979 Г.}

\author{
Чан Тхи Тхань Хуен \\ Преподаватель \\ Департамент языков и культур Юго-Восточной Азии \\ ВНУ Университет языков и международных исследований \\ Аспирант \\ Факультет востоковедения, \\ ВНУ Университет соичальных и гуманитарных наук \\ Г. Ханой, Вьетнам \\ Фан Минь Чау \\ Преподаватель \\ Кафедра вьетнамских исследований, Факультет профессионального развития \\ Педагогический колледж Туа Тхиен Хюэ, \\ Хюэ, Вьетнам \\ Аспирант \\ Факультет востоковедения, \\ ВНУ Университет социальных и гуманитарных наук \\ Г. Ханой, Вьетнам
}

\footnotetext{
Abstract. South Korea and Singapore faced several challenges in the early 1960s, including unemployment, ethnic conflicts, rising crime, etc. Faced with that situation, President Park Chung Hee and Prime Minister Lee Kuan Yew conducted a strategic plan and launched a series of appropriate policies to recover the country's economy. The plans to develop human resources for domestic industry are key factors deciding the success of these two countries. It is also the secret for them to achieve their current remarkable and miraculous progress. In this paper, the authors uses historical analysis, statistical method, comparative method, and data analysis to study some human resource development strategies of South Korea and Singapore from 1961 to 1979. Thereby, the author will find out the similarities and differences in their development strategies.

Аннотация. Южная Корея и Сингапур столкнулись с рядом проблем в начале 1960-х годов, включая безработицу, этнические конфликты, рост преступности и т.д. Столкнувшись с этой ситуацией, президент Пак Чон Хи и премьер-министр Ли Куан Ю разработали стратегический план и начали ряд соответствующих мер политики по восстановлению экономики страны. Планы по развитию человеческих ресурсов для отечественной промышленности являются ключевыми факторами, определяющими успех этих двух стран. Это также секрет их нынешнего замечательного и чудесного прогресса. В этой статье авторы используют исторический анализ, статистический метод, сравнительный метод и анализ данных для изучения некоторых стратегий развития человеческих ресурсов в Южной Корее и Сингапуре с 1961 по 1979 год. Тем самым автор обнаружит сходства и различия в их стратегиях развития.
} 
Vietnam

Keywords: Service quality, quality of training, higher education, satisfaction, learner satisfaction, Education in

Ключевые слова: качество услуг, качество обучения, высшее образование, удовлетворенность, удовлетворенность учащихся, образование во Вьетнаме.

\section{Status of human resources in South Korea and Singapore in the early 60s}

In the early 1960s, South Korea and Singapore faced many difficulties. After the Korean War (1950-1953), South Korea became one of the poorest countries in the world, often facing starvation due to extreme weather conditions, unemployment, increase in crime rate, rapid population growth, migration from rural to urban areas, widespread unemployment, and low demand for skilled workers. The qualifications and skills of workers were limited. The proportion of untrained workers accounted for $44.7 \%$ [6, p. 350]. The workforce in the agricultural sector accounted for 66\%. [11, p. 147]. Faced with this situation, President Park Chung Hee had implemented some policies to promote the economy and develop the country, including a human resource development strategy.

Singapore is a nation that is multi-ethnic, multilingual, and almost devoid of natural resources. Singapore faced numerous pressing issues following its independence, including security, ethnic conflicts, unemployment, etc. Compared with many other countries at the time, Prime Minister Lee Kuan Yew described Singapore as having a "terrible disparity and uncertain future of survival" [8, p. 19]. In 1960, the number of employees working in the service sector accounted for $69 \%$, which was three times higher than those working in the industry, which accounted for $23 \%$ [11, p. 147]. The qualification of Singaporean employees who had never been educated in schools accounted for more than half of the total, with the actual data in 1966 being 54.1\% [6, p. 350]. Singaporean workers mainly worked in the fields of maritime, processing sector, and service. Moreover, in the post-war period, the population rate increased due to increasing numbers of immigrants to Singapore, leading to an increase in unemployment. Therefore, the government should prioritize solving unemployment and training human resources for the industrialization strategy.

Faced with a shortage of skilled workers, a high unemployment rate, and the demands of industrialization, South Korea and Singapore determined that focusing on human resource development and possessing a highly qualified and specialized workforce were critical. After taking over the government and implementing groundbreaking undertakings and policies, both Park Chung Hee and Lee Kuan Yew realized that one of the key goals was to transform the economy, which was in a third-world, to being in a first-world.

\section{Some policies to improve the quality of human resources in South Korea and Singapore}

In terms of export-oriented strategy, both South Korea and Singapore have taken advantage of available human resources, bringing efficiency to the labor-intensive export industry. The two governments have taken a range of measures to enhance the quality of human capital, ensure the needs of society, and meet the demands of domestic economic growth, including:

Investing in education: Before the 60s, South Korea's Lee Seung Man government (1948-1960) applied many measures for education reform, but human resources also failed to meet the demands of the country's economic growth. Cultural education was considered a second economy during President Park Chung Hee's tenure, and it became an integral part of economic growth. Between 1961 and 1979, the State budget for education increased dramatically.

Summary of the State budget and the budget of the Ministry of Education of South Korea from 1961 to 1979 [13].

\begin{tabular}{|c|c|c|}
\hline Year & State budget & Budget of the Ministry of Education (Unit: Million dollars) \\
\hline 1961 & 69.423 & 7.598 \\
\hline 1970 & 446.273 & 78.478 \\
\hline 1979 & 5.213 .435 & 884.924 \\
\hline
\end{tabular}

During this period, South Korea significantly increased its budget for education. From 1961 to 1970, the state budget for education increased about ten times. By 1979, this budget had increased more than 100 times. The table indicates that the Korean government has focused on investing in education and putting people at the heart of the national development strategy.

Singapore's Prime Minister Lee Kuan Yew determined that education is the only way for the country to transform. He also emphasized that if they won the educational race, they would win the economic race. "We have to invest in it more than in any other industry," [7] he said. Therefore, the State's investment budget for education also grew dramatically during this period.

Table 2

The Government budget for education of Singapore between 1961 and 1979 [4, p. 152; 5, p. 18-21].

\begin{tabular}{|c|c|}
\hline Year & Government budget for education (S\$) \\
\hline 1961 & 6.649 .800 \\
\hline 1970 & 184.586 .000 \\
\hline
\end{tabular}


Like South Korea, Singapore invested a significant amount of money in education. Singapore's investment in education was the highest in Asia between 1960 and 1970. The average annual cost of education accounted for about $20 \%$ of the total national budget. The Singapore government spent 6,649,800 S\$ in education in 1961, but by 1979 , this investment had risen by more than 80 times. The government increased subsidies for education and training to provide universal education, open many vocational schools, and create significant opportunities for all people.

Focusing on developing education: Based on improving the quality of human resources and meeting economic needs, South Korea and Singapore had made efforts to develop education.

For primary education: To rapidly develop human resources for industrialization, the government of South Korea implemented education reform, invested funds for education, increased the number of teachers and teaching aids in schools, and expanded the system of public and private schools. In addition, it also carried out illiteracy eradication programs and enhanced knowledge for the elderly.

Between 1961 and 1979, the percentage of primary school students enrolled rose to nearly $100 \%$. The government concentrated on education reform and increasing the number of students attending schools. Although the government of South Korea did not offer free primary education at the time, the enrollment rate was already rapidly rising.

At this time, Singapore implemented many policies and measures to improve the quality of education. In particular, the primary focus of its education policy was meeting the needs of industrialization. Furthermore, Singapore placed a high value on free primary education. Compared with South Korea's education, Singapore's education in this period made a difference, which was implementing a bilingual policy. In 1966, Singapore stipulated that all primary school students had to learn bilingualism (studying English parallel with their mother tongue). It is a significant turning point in Singapore's history, which defines its identity and creates equality and job opportunities for people. The popularity of English has given Singapore an advantage in many aspects, contributing to favorable conditions for attracting FDI and allowing this Island Nation to respond to globalization more rapidly than South Korea.

For vocational education and training: Since high school, South Korea had concentrated on vocational education to create skilled human resources for industrialization. After entering high school, South Korean students had two options: high school education and vocational training. The quality of training increased markedly compared to the period before 1960 thanks to this program.

Meanwhile, in Singapore, all students at the secondary schools began vocational training. One-third of the final year students studied engineering, and the remaining two-thirds continued to study in general classes. Accordingly, the number of secondary school students majoring in engineering increased from 1,600 students in 1968 to more than 7,000 students in 1972 [10, p. 5]. The secondary level was categorized into a variety of programs. The primary programs were designed to prepare knowledge for students before entry into vocational schools or technical colleges. The remarkable thing was that Singapore divided knowledge scientifically rather than leveling it. Therefore, learners were assessed based on their cognitive ability. Gifted students had a separate curriculum. All of the learner's skills were encouraged to develop their full potential.

In addition, South Korea and Singapore also focused on expanding vocational schools and professional competency training centers.

The government of South Korea paid attention to developing professional education and the training of technical workers and management teams. It issued some laws and policies on developing human resources to meet the needs of the economy. According to a report of South Korea's Office of Employment and Labor in 1971, more than 15,000 workers were trained, contributing to the rapid growth of enterprises during that time [9, p. 30]. Along with the development of industry, the government also encouraged the development of high-quality human resources. In addition to state-owned training institutions, it allowed private organizations to form and establish training institutions in different types of training. In 1967, 36 vocational training establishments offered 32 occupations. There were 75 occupations in 158 vocational training institutions by 1970 [12, p. 911]. Enterprises with large-scale production also provided specialized training for their employees. The Act on Vocational Training was passed in 1967, requiring businesses with more than 500 workers to have annual training programs. In addition, engineers and officials were sent abroad to acquire and master the necessary skills under the training method for each position. This approach helped the State train high-quality human resources and enhanced the ability to use technology in manufacturing. The government also gave financial support for multinational companies to participate in technical training centers, allowing employees to gain manufacturing expertise from the world's leading corporations' technical training courses. In 1979, more than 90,000 qualified workers were trained and provided the labor market through in-plant vocational training [9, p. 33]. At the same time, the government offered scholarships and financial support to encourage multinational companies to invest in Singapore by sending key staff abroad for training.

During this period, Singapore also established vocational training centers to train skilled workers and technicians to serve industrial development. Unlike South Korea, vocational schools in Singapore were established and managed by the State. Their training program was built by the Technical Education Department (TED Technical Education 
Department). The number of students graduating from vocational institutes increased from 324 in 1968 to 4,000 in 1972. This number increased more than ten times in 5 years in Singapore's vocational schools and institutes. In addition to formal vocational training in schools, Singapore also aimed to provide additional training for many subjects, ages, and career orientations to expand labor resources in industrial production.

Work management: In the early 1960s, the economy of South Korea lacked capital, technology, and human resources, both unskilled labor and skilled labor. In the early stages of import-substituting industrialization, South Korea focused on developing the light industry. Its government had effectively exploited the source of cheap labor for basic jobs. By the early 70s, South Korea had become a promising country in labor-intensive industries such as textiles and footwear. To manage human resources effectively, managers considered creating job opportunities to manage workers in the factory. Employees will not be permitted to work overtime if they do not adhere to the labor discipline of the factory and manager. In addition, managers also set norms and regulations on workers' compensation.

Thanks to foreign investment into export manufacturing industries, Singapore has created a lot of jobs for its people. During the 1960s-1970s, the construction industry developed strongly. The processing industry proliferated, making Singapore need a large number of workers. The growth in new employment between 1957 and 1970 was 6\% per year, rising to 8.5 percent per year in the 1970s. From 1966 to 1973, the processing industry created nearly 150,000 jobs, decreasing the unemployment rate in Singapore from 9\% in 1966 to 4.5\% in 1973 [1]. Unlike South Korea, which managed employees with overtime and regulations on bonuses and punishment, the Singapore government established the National Wages Council (NWC) and built a tripartite institution to benefit employees, enterprises - organizations, and the country. Singapore had an additional source of foreign workers in the second half of the 1970s, which played an indispensable role in the country's economic development. Singapore had almost used up all of its workers and had become a popular destination for foreign workers, who made up 3.2\% of the workforce. Singapore had nearly achieved full employment by 1979 with an unemployment rate of 3.3\% [3, p. 95].

Attracting and respecting talents: South Korea and Singapore had policies to attract and recruit talents in their national development strategies. Recognizing that after independence, the country was still facing many difficulties, President Park Chung Hee and Prime Minister Lee Kuan Yew considered people a national resource. Their talent was a critical factor determining the development of the domestic economy.

President Park Chung Hee of South Korea considered attracting talent a part of the national growth strategy since the 1960s to turn this country into an industrialized and modernized country. He established the Economic Planning Board, which gathered elite experts trained in the US, UK, and Japan, such as Song Yo Chan, Kim Yu Taek, and Park Choong Hoo. Accordingly, investing in and cultivating talents in South Korea was increasingly focused, which was reflected in the increase in funding for developing science and technology and paying high wages for highly qualified workers. Therefore, the salary was a motivation for employees to devote themselves to work. The salary depended on the educational level and work experience of the newly hired employee. At the same time, the Government also had a periodical salary increase according to seniority. The bonus and promotion were based on the results of the annual evaluation. To prevent brain drain, in 1966, South Korea established the Korea Institute of Science and Technology (KIST) with a variety of incentives for compensation, including high salaries equivalent to American scientists and providing accommodation and workplaces. Furthermore, overseas Korean researchers majoring in basic technology and advanced technology in a period of five years would be excluded from military service. Before 1970, most Koreans who obtained a doctorate in the United States did not return home country. However, after 1970, the number of Koreans who stayed in the US after receiving a doctorate decreased significantly thanks to the Government's preferential policies. It can be said that the gathering of the nation's wisdom has made a substantial impact on the socio-economic development of South Korea.

Singapore is a multi-ethnic and multilingual country, so Prime Minister Lee Kuan Yew has focused on attracting talent both within and outside the country regardless of ethnic group, nationality, and religion. "Every outstanding talent has a chance to be appointed to high positions" [2, p. 37]. He built the country together with highly educated colleagues, such as Ngo Khanh Thuy, Ngo Tac Dong, etc. Because of Singapore's unique circumstances, a small Island Nation that lacked natural resources, he looked for the talented everywhere. All talents could be appointed to high positions through open selection and fair and honest competition. The method of selecting and promoting talents to job positions was rigorous. The selection was made equitably, transparently, and objectively. In particular, there were no negative manifestations, bribery, corruption, or the phenomenon of using money to bribe and promote. The Government also established the Committee for Attracting Talent to Singapore (CATS) that mainly focused on Asian talents and had perfect remuneration policies. Through the Professionals Information and Placement Service (PIPS), young talents could undertake jobs suitable to their expertise and forte, enjoyed high salaries, and be provided with a house. Talents who came to Singapore to study and work could settle permanently and get Singapore citizenship easily. A team visited talented Asian students at universities to attract them to work in Singapore thanks to the support of advisors from delegations in the United Kingdom, the United States, New Zealand, and Canada. For people with outstanding achievements, this Committee had strived to offer suitable jobs before they graduated. In addition, Singapore had founded two specialized agencies to attract talents from India and other countries in the region. It also offered hundreds of scholarships to outstanding students from China, India, and other countries in Asia. It hoped that some of them would 
stay in Singapore because of better job opportunities. If some returned to their home country, they could be helpful to Singaporean companies abroad.

It can be said that policies of Singapore and South Korea for attracting and employing talent have had a significant effect on promoting economic growth, especially in the technology sector.

In addition to the mentioned policies to improve the quality of human resources, Singapore and South Korea have also implemented several policies such as reducing population growth, developing critical education, and raising people's living standards.

\section{Reviews}

Firstly, South Korea and Singapore valued human resources and identified people as national resources between 1961 and 1979. During the early years of industrialization, this force contributed to the economy and built the country. Both South Korea and Singapore have implemented quite comprehensive strategies and measures to encourage the full importance of human resources. Despite their differences, both policies have a lot in common.

The similarities of South Korea and Singapore in improving the quality of human resources are that they both consider people national resources, paying attention to investing in and developing education from the grassroots, raising the people's intellectual standard, managing human resources, and creating policies of appreciating, cultivating, and attracting talents. The model of vocational schools, human resource orientation and training, and policies linked to human resource development are some of the distinctions between South Korea and Singapore from 1961 to 1979. The difference in human resource training and orientation comes from the different development models of the two countries. Singapore aimed to become a financial, commercial, and service center, whereas South Korea followed the industrialization model from low to high level.

Secondly, from 1961 to 1979, under President Park Chung Hee's leadership, South Korea transformed swiftly with development programs. Singapore had shown a stunning transition under Prime Minister Lee Kuan Yew's leadership, demonstrating the robust growth of a young nation. The human resources of both countries, cared for, developed, and invested in the right direction, had created many achievements. This factor helped South Korea and Singapore quickly become two newly industrialized countries, whose market share in industrial output and the export of manufactured goods increased rapidly from the early 1960s and especially in the 1970s.

Thirdly, the economies of South Korea and Singapore increased strongly. The GDP of South Korea rose significantly. South Korea's per capita income had increased by more than 20 times in the last 18 years, from $\$ 84$ in 1961 to \$1,713 in 1979. Meanwhile, Singapore's GDP growth was equal to that of South Korea, even though it was a small country. The number of enterprises increased by more than four times, and the number of workers climbed up ten times. The GDP per capita of the two countries remained progressive, rising from $\$ 449$ in 1961 to $\$ 4,078$ in 1979.

Thanks to the constant efforts combined with the right human resource development policies, South Korea and Singapore have become two of the most developed countries in Asia with high per capita income.

Lastly, thanks to policies to improve the quality of human resources, South Korea and Singapore have gathered a team of skilled workers and a team of good, qualified, and responsible officials. It can be affirmed that human resources play a significant role in national economic growth. However, possessing high-quality human resources is also a challenge for South Korea, Singapore, and many countries due to socio-economic development.

\section{Conclusion}

South Korea and Singapore had adequate policies to develop human resources from 1961 to 1979 . The reality of the two countries' economies in this period demonstrates that human resource is one of the significant factors promoting the development of the economy and the country. At the same time, the success of these two countries also affirms the critical role of the Government and the Head of State in planning and implementing policies. It can be said that the Government and the Head of State are vital human resources and talent resources that determine a country's success or failure.

\section{Список литературы / References}

1. Duong Van Quang. Singapore - Features and solutions. Hanoi: National Political Publishing House, 2007.

2. Le Tu Vinh and Nguyen Huy Quy . Collection of 40 political essays by Lee Kuan Yew. Hanoi: National Political Publishing House, 1994.

3. Choon, hoon, Chia Ngee. Social Protection in Singapore: Targeted Welfare and Asset-based Social Security, in Asher, M. G., S. Oum and F. Parulian (eds.), Social Protection in East Asia - Current State and Challenges, ERIA Research Project, 2009.

4. Department of Statistics. Yearbook of Statistics Singapore 1967-1970. Singapore, 1971.

5. Department of Statistics. Singapore Annual Key Indicators 1971-1980. Singapore, 1981.

6. Gary S. Fields. Industrialization and Employment in Hong Kong, Korea, Singapore, and Taiwan / W. Galenson (ed.) Foreign Trade and Investment: Economic Development in the Newly Industrializing Asian Countries. Madison, Wis : University of Wisconsin Press, 1985.

7. Lee Kuan Yew online. Prime Minister's Address on TV on The Eve of National Date, 8th August, 1967. 
8. Lee Kuan Yew. From Third World to First: The Singapore: 1965-2000, Memoirs of Lee Kuan Yew, Times Editions, Singapore Press Holdings, 2000.

9. Ministry of Employment and Labor - ROK. Vocational Training System for a Skilled WorkforceI, Korea, 2012.

10. Tan Peng Boo. Human Resource Development for Continued Economic Growth: The Singapore Experience, The ILO Workshop on Employers Organizations in Asia-Pacific in the Twenty-First Century, Turin, 1997.

11. The World Bank. World Development Report 1980.

12. 과학기술처 (Department of Science and Technology) (1971), 과학기술연감.

13. 문교부 (Ministry of Education). 교육통계연보 1980, table 28. 